\title{
Council Approves MRS Archival Journal, Expands Student Benefits, Develops Broad International Relations
}

The Council of the Materials Research Society meets twice a year during the annual Fall and Spring Meetings of the Society. The Council includes 15 MRS members who serve three-year terms. Five new Councillors are elected by the membership of the Society each year. The Executive Committee consisting of the Officers of the Society also serve as members of the Council. The following two reports summarize Council actions taken during the last two meetings which affect activities and services under development for the membership.

\section{MRS Council Meeting (December 1984)}

\section{R. L. Schwoebel Secretary}

The Materials Research Society Council Meeting at Boston, November 30-December 1, 1984, following the Fall Meeting of MRS, included over 35 people and considered a variety of important new features in the life of the Society. 1984 MRS President Woody White began the meeting by proclaiming 1984 a banner year for MRS. He stated that the 1984 Boston meeting was a great success and had included many fine new activities. Approximately 2,000 people attended this meeting, and as of November MRS membership totaled approximately 2,500 members. As the outgoing President of the Materials Research Society, White received from Harry Leamy the MRS Woody Award for outstanding service as President to the Society.

Some of the items covered during the Council Meeting included:

- The Council welcomed Bill Koch from the American Institute of Physics who discussed and elaborated on the possible interactions between the Materials Research Society and the American Institute of Physics. Koch recommended that MRS develop a journal as soon as possible and indicated that AIP could be of great help to MRS in this area. He noted that the infrastructure already established by AIP for journal distribution was a very important component of starting a new journal and that AIP had, in fact, considered the initiation of a journal in the materials area itself. The recommendation by Koch stimulated a good deal of discussion within the Council and in particular, John Baglin and Dave Campbell reported on their study of the possibility of initiating an MRS journal. There was very strong sentiment for initiating an archival journal and the Council agreed to instruct the Publications Committee and the Director of Publications to pursue negotiations for a journal arrangement with the American Institute of Physics. The Council also agreed that the journal should clearly reflect the broad scope of the Materials Research Society. In the area of publications, Harry Leamy also discussed plans for the MRS BULLETIN in 1985. In 1985, the BULLETIN is attempting to include a good deal more material such as editorials, book reviews, technical reviews, etc., and an editorial board is being established to oversee that activity.
- One of the new activities evident at the 1984 Fall Meeting was the establishment of a Job Placement Center. The Job Placement Center was organized for the first time by the Membership Committee, and over 100 persons interested in job placement presented resumes at the Center. In addition, 42 potential employers participated in the Job Placement Service. This service will be continued at future annual meetings of MRS.

- Rod Ewing reported on behalf of the Education Committee that a program had been developed for the Student Chapters, and direct contact had been made with several hundred materials-related departments in universities throughout North America. Several of these departments have responded and are developing active student groups. This now includes MRS-affiliated student chapters at University of Pennsylvania, Cornell University, Rensselaer Polytechnic Institute, Case Western Reserve University, and UCLA. In addition, Dick Schwoebel reported and brought to the Council meeting proposed changes in the Constitution which would included the concept of both Student Chapters and Local Sections of MRS and presented draft constitutions and bylaws for these groups which were approved by the Council.

- Benefits to student attendees will be expanded in future years, and the Council will attempt to develop a student housing locator that may be of value to students desiring to attend meetings. The Membership and Education Committees also recommended that the Council approve the inauguration of a student travel assistance program to promote attendance from various MRS Student Chapters and elsewhere. This joint committee report also recommended the inauguration of an MRS lecture program in which outstanding speakers from the annual MRS Fall Meeting will be supported to present scientific work and promote the formation of student chapters.

- Dave Zehner reviewed the short course program that was conducted at the Fall Meeting. Nine courses were offered at the meeting, and the total attendance was approximately 150 participants. This short course activity will continue at future MRS meetings, and suggestions for areas in which short courses might be held would be gratefully received by the new chairperson of this group, Ralph Dawson.

- The Materials Research Society has a growing number of corporate affiliates which now provide support for the Society. Clif Draper noted that in 1984, MRS had developed a cadre of 82 corporate affiliates and received both general and symposium direct support from them for MRS meetings.

- John Ballance presented a report on MRS Headquarters operation. He introduced the new Director of Publications, Gail Oare, and secretary of the Headquarters operation,

(continued on next page) 
Continued from previous paget

Anne Wagner. John noted that there had been substantial changes that had occurred in the last year with the inauguration of the Headquarters operation, development of the staff, incorporation of a computer, and other equipment that was assisting in the MRS Headquarters activities. He noted that last October the membership was roughly 1,525 and that membership now stands at 2,465.

- During 1984, the Publicity and Public Relations Committee under direction of Julia Phillips prepared a new brochure on MRS, which was mailed to approximately 17,000 individuals. This has produced an excellent response, and the Society is now receiving applications for membership at the rate of approximately 10-20 per week from that mailing.

- Another discussion that evoked a good deal of response on the part of the MRS Council was that dealing with MRS International activities-a concept that has been studied and considered by the Executive Committee. The Council approved the idea of forwarding European registrants copies of the MRS BULLETIN at $\$ 10.00$ per year as a way of continuing the further development of interactions with our colleagues in Europe. A number of offshore meetings will be cosponsored by MRS, including the Nuclear Waste Symposium in Sweden in September, the Royal Electron Microscopy Society meeting in England in March, and the IBMM 86 Meeting in Italy in 1986. It was felt that the Society's interactions with its European counterparts will continue to evolve over time and the MRS Council will closely monitor and encourage these interactions. Discussion held during the Boston meeting with various European counterparts also included representatives from Japan, Korea, China, and some other countries. A committee will be formed to consider the further interaction and coordination of MRS activities in other parts of the world.

\section{MRS Council Meeting (April 1985)}

$$
\text { R. C. Ewing, Secretary }
$$

The Council meeting in April 1985 in San Francisco marked the beginning of major projects and new directions that will add to the prestige and responsibilities of the Society. The Council gave final approval to the recommendation of the Publications Committee that the Society publish a broad-based interdisciplinary journal to be called the Journal of Materials Research. (See complete details of the journal elsewhere in this issue of the BULLETIN.) After considerable discussion, with particular attention to the financial obligations of the Society, the Council empowered the Executive Committee to negotiate with the American Institute of Physics a plan that would allow the AIP to publish the journal, with MRS retaining full control and ownership of the journal. The Council reviewed and approved the proposed structure of the journal and reviewed a list of candidates for the position of Editorin-Chief.

This new and important venture of the Society will require the full support of the MRS membership. The Society will draw heavily on its human resources to assemble a group of Principal Editors which reflects the diversity of the Society. Every member is encouraged to submit his or her best work for publication in this journal. The initial issue of the journal will be published February 1.

In other actions, the Council approved petitions for the formation of two new student chapters at Cornell University and Rensselaer Polytechnic Institute. The charters for both of these student chapters will be presented at the Plenary Session at the 1985 MRS Fall Meeting. The benefits to students in the Society continues to increase. The Council will provide travel funds for selected students to attend MRS meetings, in addition to its present awards for best student papers. Any institution which wants to establish a student chapter is encouraged to contact MRS Headquarters or Prof. Linn Hobbs at MIT, telephone (617) 253-6835.

L. Ralph Dawson reported on a much expanded program for short courses at MRS meetings. Fourteen short courses are scheduled for the 1985 Fall Meeting in Boston, and at least eight courses for the Spring Meeting in Palo Alto in 1986. The Council approved the cosponsorship of a course in vacuum technology with the American Vacuum Society which will be offered at the next Fall Meeting.

The Council reviewed the nomination procedure for the Von Hippel Award and increased its cash component from $\$ 1,000$ to $\$ 2,500$ beginning in calendar year 1986 . The Council also adopted a plan to initiate a series of awards to honor distinguished individuals in broad topical areas and another to honor the accomplishments of young scientists. These awards will be conferred as soon as funds are available.

In addition, the Council reviewed and approved the budget for 1985. Total expenses for the Society will be approximately one million dollars this year, and if the past years are any measure, the Society can expect continued growth.

The Council heard reports on a diverse range of other important topics: equipment exhibits at the annual meetings, corporate support for the Society, progress in establishing new MRS local sections, a report from the external affairs committee on the Society's efforts to represent the materials community in the discussion of important government actions, the continued needs and growth of the Headquarters in Pittsburgh, future MRS meeting programs, and the MRS meeting this September in Stockholm which will be the Ninth Symposium on the Scientific Basis for Nuclear Waste Management.

The Society's Councillors and Officers spent many hours considering these issues and guiding the Society in its dynamic growth. This brief report is only indicative of the broad range of activities of the Society. If you want to participate, contact an Officer of the Society. There is plenty of exciting work to be done.

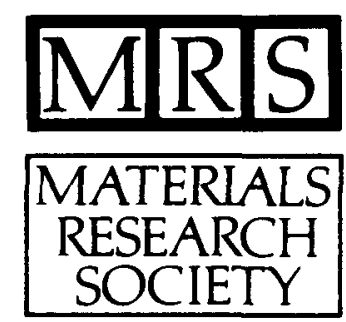

